\title{
Baltimore is Still Burning: the Rising Relevance of James Baldwin
}

\author{
Justin A. Joyce and Dwight A. McBride Northwestern University \\ Douglas Field University of Manchester
}

Keywords: James Baldwin, Freddie Gray, Michael Brown, Baltimore, police, "Black Lives Matter," Baldwin's legacy, rioting, looters

The fires, this time, are in Baltimore. They ignited rather quickly, burning bright and hot in a moment of reasonable rage. Set ablaze by the death of yet another black man in police custody, "rioters and looters" set fire to several buildings, sprayed cars and buildings with wanton gunfire, and effectively shut down the city. The family of Freddie Gray, a young African-American man who suffered a fatal spinal injury while being apprehended for possession of a knife on 12 April 2015, implored peaceful protest. In a muted echo of the rage that engulfed Ferguson, Missouri, over the shooting of Michael Brown in August of 2014, by the time of Gray's funeral on Monday, 27 April 2015, Baltimore was consumed with rage. Confrontations with police ramped up a notch, only to be quelled and contained, bricks and bottles being little match for pepper spray, riot shields, and helicopters. A state of emergency was declared.

At the time of this writing, two thousand National Guard troops have been deployed in Baltimore, joining an equal number of additional police deployed from neighboring states. Baltimore is under a curfew, stated to last at least another week. The Chicago White Sox and the Baltimore Orioles played baseball to an empty Camden Yards on Thursday, 30 April. Fearing the riotous tremor would erupt again in such a public gathering, the iconic stadium was shuttered; no tickets or concessions were sold. The Orioles won; apparently that's supposed to be a sign of hopeful progress. The 24-hour news cycle keeps telling us so. Despite numerous pundits calling for a focus on the "real issues" underlying both Gray's death and the eruption of rebellious frustration that followed, the media frenzy over the events in Baltimore predictably unraveled into arguments about whether or not it was politic to refer to rioters as "thugs." President 
Obama gave a statement, decrying the rioters' actions as "criminal." In the face of civil unrest over police treatment, criminal economic inequality, and a crippling lack of access to education or employment, baseball seems hardly more than a very weak panacea for the smoldering embers of frustration left burning in Baltimore.

A better answer, perhaps, lies in the words and legacy of James Baldwin. Many seem to think so at this time. The Baltimore Sun reports that one demonstrator outside the Western District police station on Monday held a sign emblazoned with a quote from Baldwin, "Ignorance allied with power is the most ferocious enemy of justice." ${ }^{\prime 1}$ Further snippets and quotes from Baldwin's writings and interviews appeared across the Internet. Many found particular saliency, perhaps solace, in this moment by looking back to Baldwin's response to another moment of rioting and looting in Baltimore. Interviewed by Esquire in July of 1968 just on the heels of rioting, looting, and protracted civil unrest that engulfed more than a hundred other cities in the U.S. after Martin Luther King, Jr's assignation that April, Baldwin is asked a series of questions about what it will take to get blacks to "cool it." A lifelong opponent of classificatory schemes of all sorts, Baldwin begins by objecting to the term "looters," wonders "who is looting whom," and goes on to describe the rage and frustration being expressed through such acts:

how would you define somebody who puts a cat where he is and takes all the money out of the ghetto where he makes it? Who is looting whom? Grabbing off the TV set? He doesn't really want the TV set. He's saying screw you. It's just judgment, by the way, on the value of the TV set. He doesn't want it. He wants to let you know he's there. The question I'm trying to raise is a very serious question. The mass media-television and all the major news agencies-endlessly use that word "looter." On television you always see black hands reaching in, you know. And so the American public concludes that these savages are trying to steal everything from us, and no one has seriously tried to get where the trouble is. After all, you're accusing a captive population who has been robbed of everything of looting. I think it's obscene. ${ }^{2}$

Others attempting to provide perspective or commentary on the fire of outrage erupting in Baltimore over the least several days have found expression through Baldwin's commentary on police and racial violence from his 1960 essay, "Fifth Avenue, Uptown: A Letter from Harlem:"

The white policeman standing on a Harlem street corner finds himself at the very center of the revolution now occurring in the world. He is not prepared for it-naturally, nobody is-and, what is possibly much more to the point, he is exposed, as few white people are, to the anguish of the black people around him. Even if he is gifted with the merest mustard grain of imagination, something must seep in. He cannot avoid observing that some of the children, in spite of their color, remind him of children he has known and loved, perhaps even of his own children. He 
knows that he certainly does not want his children living this way. He can retreat from his uneasiness in only one direction: into a callousness which very shortly becomes second nature. He becomes more callous, the population becomes more hostile, the situation grows more tense, and the police force is increased. One day, to everyone's astonishment, someone drops a match in the powder keg and everything blows up. Before the dust has settled or the blood congealed, editorials, speeches, and civil-rights commissions are loud in the land, demanding to know what happened. What happened is that Negroes want to be treated like men. ${ }^{3}$

More examples of the prescience and contemporary poignancy of Baldwin's words could certainly be marshaled. Indeed, the ongoing relevance of Baldwin is a double-edged sword for scholars of his life and works. Each triumph of broadening access and exposure to his brilliant writing is a moment for celebration; yet each time the social and political landscape of a moment calls out for Baldwin's critical insight we are reminded of the ongoing necessity for change. "We have a civil rights bill now," Baldwin wrote in "The American Dream and the American Negro," an essay published fifty years ago. "We had the 15th Amendment nearly 100 years ago. If it was not honored then, I have no reason to believe that the civil rights bill will be honored now."4

While Baldwin lost faith in the American political system, his writing never lost hope in people's capacity to change. "Jimmy was not bitter," Maya Angelou recalled. "What Jimmy was, was angry. He was constantly-He was angry at injustice, at ignorance, at exploitation, at stupidity, at vulgarity." ${ }^{5}$ Amidst Baldwin's anger, his writing frequently confounded his readers, demanding the unexpected. In The Fire Next Time, published in 1963, at a time newspaper headlines chronicled daily racial tension, Baldwin called upon "the relatively conscious whites and the relatively conscious blacks" to work together, not as neighbors, but as "lovers." In contrast to mainstream political rhetoric, Baldwin's prose exposed the hidden complexities of contemporary U.S. life. Where Obama decries the looters as criminal, Baldwin pointed out that the legal system is itself a "criminal power."7 "Every society is really governed by hidden laws," Baldwin wrote, and "it is up to the American writer to find out what those laws and assumptions are," a task that he set himself, and one that he certainly fulfilled. ${ }^{8}$

Written in 1999 about the moment of cultural studies' ascendency within the American academy, Dwight A. McBride's edited collection, James Baldwin Now, suggested the beginnings of a return to Baldwin, a renewal made possible by the radical potential of critical dialogue:

It is common fare in critical discourse today to talk of transnationality and the new ways in which that category requires us to understand other categories, such as identity. The fact that we can today think about the complicated relationships that not only obtain but are inevitable between race, gender, class, and sexuality makes 
possible a reassessment and a critical treatment of Baldwin that perhaps was not before imaginable. ${ }^{9}$

It is our incredible editorial good fortune that the inaugural volume of this journal will be premiering at the crest of this wave of reassessment of James Baldwin as an integral figure in twentieth-century American letters. This reassessment has taken numerous forms over the fifteen years since McBride's volume appeared. International conferences dedicated to Baldwin have been convened in Washington D.C. (2000), London (2007), Boston (2009), New York (2011), and Montpellier (2014); another conference is planned for Paris in 2016. Pioneering new scholarship such as D. Quentin Miller's edited volume, Re-Viewing James Baldwin: Things Not Seen (2000), Herb Boyd's new biography, Baldwin's Harlem (2008), Magdalena Zaborowska's James Baldwin's Turkish Decade (2009), Randall Keenan's edited volume of Baldwin's uncollected writings, The Cross of Redemption (2010), Cora Kaplan and Bill Schwarz's edited collection, James Baldwin: American and Beyond (2011), D. Quentin Miller's A Criminal Power: James Baldwin and the Law (2012), Matt Brim's James Baldwin and the Queer Imagination (2014), Douglas Field's All Those Strangers: The Art and Lives of James Baldwin (2015), and Michele Elam's edited collection, The Cambridge Companion to James Baldwin (2015), have continued to expand our understanding of both Baldwin's writings and his personal life. Alongside these academic works, a year-long celebration of his life and legacy, "The Year of Baldwin" was organized in New York in 2014 to mark what would have been his 90th year. Jewelle Gomez's play, Waiting for Giovanni, premiered in San Francisco in 2011 and a production of The Amen Corner was staged at the National Theater in London in 2013; both testify further to the ongoing public interest in Baldwin's works, just as the seeming ever-readiness for journalists and pundits alike to call upon his critical voice in moments of tragedy testifies to our need for an artist whose searing words can so uniquely lay bare the demands of a time, people, or nation.

It is not our aim here, necessarily, to decry those who've marshaled Baldwin's writings to elucidate or explain a contemporary calamity. In a way it could scarcely be otherwise: Baldwin positioned himself, across various media and a variety of genres, foremost as a "witness."10 As a witness, Baldwin worked and wrote of all the truths that "I've seen and the possibilities that I think I see."11 This impetus to tell the truths, especially the darker, less flattering truths about our history and ourselves that so often get elided, is how Baldwin imagined his words would make an impact in the world. For only by exposing the truths can change ever spring forth. In his own words, "Not everything that is faced can be changed; but nothing can be changed until it is faced." 12 In the face of a riotous upheaval, then, Baldwin's fiery rhetoric surely lends itself to being marshaled as evidence, explanation, or even as witness to the historical breadth of the problems being suffered in the ever-present American "now." 
Though it has long been a commonplace assertion within academic scholarship that Baldwin's work and reputation has not been given its due, the renaissance of interest in his work undertaken in the last half generation of scholarship represents possibilities of real hope and promise. Prospects lie in the new readers being touched by Baldwin's work, and the technologies of access and distribution in our current moment of "digital humanities" make this a time of unprecedented possibility. Making his words accessible to non-specialists, extending discussion of his writing and its impacts beyond academia, is one of the aims of the James Baldwin Review. To this end, the journal will be published online, available for free, in an open access partnership between Northwestern University, Manchester University Press, and Manchester University Library. This partnership was formed under a shared vision to publish a journal that can contain a multitude of voices and perspectives, a truly multidisciplinary forum for the growing international community of Baldwin scholars, students, and enthusiasts.

The inaugural volume of the James Baldwin Review collected here contains a mix of formal and informal tones, of experienced writers and new voices. Since each piece begins with an abstract, a summation of the contents would be superfluous here. These essays are accompanied by an award-winning graduate student essay, as well as a review of significant scholarly works on Baldwin. Our first volume also proudly features new words and new works to examine and explore, including an interview with Baldwin that has not previously been published in English and an essay on "The Hallelujah Chorus," Baldwin's largely forgotten collaboration with Ray Charles. This volume's incisive academic essays are complemented in these pages by journalistic and autobiographical reflections on Baldwin's life and work; extended discussions of the importance of music to Baldwin's life and work are accompanied by sound performances on the $J B R$ website.

It is perhaps a poignant irony on the complexities of Baldwin's legacy as an inspirational writer and self-proclaimed "disturber of the peace," that James Baldwin Way is now the official designation for a stretch of 128th street in New York. Having a street named after an author whose own titles-No Name in the Street, Nobody Knows My Name, Another Country, "Stranger in the Village"bespeak a profound sense of rootlessness and alienation is a bold step towards ensuring his continued legacy. However, reclaiming Baldwin as a "son of Harlem" does little to unsettle, or even to lay bare, the complex of social, political, personal, and moral reasons which compelled Baldwin's own exile from his native country. "You never leave home," Baldwin stated. "You take your home with you. You better. Otherwise you're homeless." ${ }^{13}$ With a street designation, a thriving revitalization of interest in his work and life by academics, journalists, artists, and enthusiasts alike, the launch of an annual journal dedicated to James Baldwin suggests that Baldwin may indeed have finally begun to find his proper home in American letters. No small thing for a man who saw his role as writer and witness - to say nothing of his life as a black man, or of his life as a queer 
black man-as profoundly alienating. As he wrote in "Mass Culture and the Creative Artist," Baldwin was acutely aware that the witness is rarely appreciated for her efforts at exposing the truths: "those who are driven to make this effort are by virtue of this fact somewhat removed from the people. It happens, by no means infrequently, that the people hound or stone them to death. They then build statues to them, which does not mean that the next artist will have it any easier." 14

The task before us here today is not to make the truth-telling task of the artist any easier; for the truths needed are very often the hardest ones to hear. Rather, we think it prudent to mark this moment by closing with an extended quote from James Baldwin on the perils that lie ahead:

We persist in believing that the empty and criminal among our children are the results of some miscalculation in the formula (which can be corrected); that the bottomless and aimless hostility which makes our cities among the most dangerous in the world is created, and felt, by a handful of aberrants; that the lack, yawning everywhere in this country, of passionate conviction, of personal authority, proves only our rather appalling tendency to be gregarious and democratic. We are very cruelly trapped between what we would like to be and what we actually are. And we cannot possibly become what we would like to be until we are willing to ask ourselves just why the lives we lead on this continent are mainly so empty, so tame, and so ugly.

This is a job for the creative artist ... Perhaps life is not the black, unutterably beautiful, mysterious, and lonely thing the creative artist tends to think of it as being; but it is certainly not the sunlit playpen in which so many Americans lose first their identities and then their minds.

I feel very strongly, though, that this amorphous people are in desperate search for something which will help them to re-establish their connection with themselves, and with one another. This can only begin to happen as the truth begins to be told. We are in the middle of an immense metamorphosis here, a metamorphosis which will, it is devoutly to be hoped, rob us of our myths and give us our history, which will destroy our attitudes and give us back our personalities. ${ }^{15}$

Shepherding change is lonely, isolated work at times. Certainly it seemed so for Baldwin. It seems hardly less so today, caught as we still are in the grip of our continued dedication "not to change a situation but to seem to have done it."16 Beyond direct confrontations and demonstrations of outrage, howsoever merited they may be, systemic change cannot be marshaled without collaboration. As a forum for sustained engagement with Baldwin's insights, contributions, and challenges, the James Baldwin Review seeks to nourish the already blossoming worldwide attention Baldwin's life and work continues to inspire, thereby providing a collaborative venue for our own time's necessary metamorphoses. 


\section{Notes}

1 Yvonne Wenger, Kevin Rector, and Mark Puente, "March on Baltimore: 'All night, all day, we will fight for Freddie Gray,"” Baltimore Sun, (26 April 2015) http://www. baltimoresun.com/news/maryland/baltimore-city/bs-md-ci-freddie-gray-march20150425-story.html\#page=1 (accessed 30 April 2015). The original quote from Baldwin appears in No Name in the Street (New York, Vintage, 1972), p. 149.

2 "James Baldwin Tells Us All How to Cool It This Summer," Esquire, (July 1968). Reprinted online (26 April 2015) http://www.esquire.com/news-politics/interviews/ a23960/james-baldwin-cool-it/ (accessed 30 April 2015).

3 "Fifth Avenue, Uptown: A Letter from Harlem," originally published in Esquire July 1960. Reprinted in Nobody Knows My Name (New York, Vintage, 1961), pp. 56-71, 67.

4 Baldwin, "The American Dream and the American Negro," (1965) in Toni Morrison (ed.), Collected Essays (New York, Library of America, 1998), pp. 714-19, 716.

5 James Baldwin: The Price of the Ticket, Directed by Karen Thorsen. PBS. 1990.

6 James Baldwin, “The Fire Next Time," (1962) in Collected Essays, pp. 291-347, 346.

7 Ibid., p. 300.

8 James Baldwin, "The Discovery of What it Means to be an American," (1959) in Collected Essays, pp. 137-42, 142.

9 Dwight A. McBride, "Introduction," in Dwight A. McBride (ed.), James Baldwin Now (New York, NYU Press, 1999), pp. 1-9, 9.

10 Julius Lester, "James Baldwin-Reflections of a Maverick," New York Times (27 May 1984), Sunday, Late City Final Edition section 7; p. 1, column 1.

11 Ibid.

12 James Baldwin, “As Much Truth as One Could Bear," (1962) in Randall Kenan (ed.), The Cross of Redemption: Uncollected Writings (New York, Pantheon, 2010), pp. 28-34, 34.

13 The Price of the Ticket, 1990.

14 James Baldwin, "Mass Culture and the Creative Artist: Some Personal Notes," (1959) in The Cross of Redemption, pp. 3-6, 4.

15 Ibid., pp. 5-6.

16 James Baldwin, “The Artist's Struggle for Integrity," (1963) in The Cross of Redemption, pp. 41-7, 47.

\section{Works Cited}

Baldwin, James, "Fifth Avenue, Uptown: A Letter from Harlem," (1960) in Nobody Knows My Name: More Notes of a Native Son (New York, Vintage, 1961), pp. 56-71.

— "The American Dream and the American Negro," (1965) in Toni Morrison (ed.), Collected Essays (New York, Library of America, 1998), pp. 714-19.

"The Discovery of What it Means to be an American," (1959) in Toni Morrison

(ed.), Collected Essays (New York, Library of America, 1998), pp. 137-42.

"The Fire Next Time," (1962) in Toni Morrison (ed.), Collected Essays (New

York, Library of America, 1998), pp. 287-347.

"As Much Truth as One Could Bear," (1962) in Randall Kenan (ed.), The Cross

of Redemption: Uncollected Writings (New York, Pantheon, 2010), pp. 28-34. 
"Mass Culture and the Creative Artist: Some Personal Notes," (1959) in Randall Kenan (ed.), The Cross of Redemption: Uncollected Writings (New York, Pantheon, 2010), pp. 3-6.

"The Artist's Struggle for Integrity," (1963) in Randall Kenan (ed.), The Cross of Redemption: Uncollected Writings (New York, Pantheon, 2010), pp. 41-7.

Lester, Julius, "James Baldwin-Reflections of a Maverick," New York Times, 27 May 1984, Sunday, Late City Final Edition section 7; p. 1, column 1.

McBride, Dwight A. (ed.), James Baldwin Now (New York, New York University Press, 1999).

No Author Listed, "James Baldwin Tells Us All How to Cool It This Summer," Esquire, July 1968. Reprinted online (26 April 2015) http://www.esquire.com/news-politics/ interviews/a23960/james-baldwin-cool-it/ (accessed 30 April 2015).

Thorsen, Karen, (dir.) James Baldwin: The Price of the Ticket, PBS, 1990.

Wenger, Yvonne, Rector, Kevin and Puente, Mark, "March on Baltimore: 'All Night, all Day, we Will Fight for Freddie Gray,"” Baltimore Sun, 26 April 2015, http://www. baltimoresun.com/news/maryland/baltimore-city/bs-md-ci-freddie-gray-march-

20150425-story.html\#page=1 (accessed 30 April 2015).

\section{Contributors' Biographies}

Justin A. Joyce is a postdoctoral fellow with The Graduate School at Northwestern University. He holds a Ph.D. in English from the University of Illinois at Chicago, where he was thrice a N.C.A.A. Academic All-American as a member of the men's gymnastics team. His work on the American Western genre, gun violence, and self-defense, which has appeared in the journal Western American Literature (2012) and The Last Western: Deadwood and the End of American Empire (Bloomsbury, 2013), is the subject of his first monograph, Gunslinging Justice: The American Culture of Gun Violence in Westerns and the Law, currently under review with the University of Illinois Press. Coeditor of two posthumous publications, The Delectable Negro: Human Consumption and Homoeroticism in U.S. Slave Culture (NYU Press, 2014) and Racial Blackness and the Discontinuity of Western Modernity (University of Illinois Press, 2014), Justin's work in African-American literature and theory has also appeared in The Oxford Guide to the African American Slave Narrative (Oxford UP, 2014), and A Historical Guide to James Baldwin (Oxford UP, 2009). Coeditor of A Melvin Dixon Critical Reader (Mississippi University Press, 2006), Joyce is currently coediting two collections of critical essays, Keywords for African American Studies (SUNY Press) and Whose Beloved Community: Black Civil and LGBT Rights (Univ. of Illinois Press).

Douglas Field is lecturer in 20th century American Literature at the University of Manchester. He is the editor of American Cold War Culture (Edinburgh UP, 2009), A Historical Guide to James Baldwin (Oxford UP, 2009), and the co-editor of a special issue on James Baldwin for African American Review (2013). He is the author of James Baldwin (Writers and Their Work, 2011) and All Those Strangers: The Art and Lives of James Baldwin (Oxford UP, 2015). Field's work on American literature and culture has been published in journals including Callaloo, English Literary History, African American Review and Literature and Theology, as well as the Times Literary Supplement, where he is a frequent contributor. His current projects include curating an exhibition of Jeff Nuttall's 
work (2016), several projects focused on William Burroughs, and completing The Beat Generation: The Literature and Lives of a Counter Culture for Edinburgh UP.

Dwight A. McBride is the Associate Provost for Graduate Education, Dean of the Graduate School, and Daniel Hale Williams Professor of African-American Studies, English, and Performance Studies at Northwestern University. An award-winning author of numerous publications that examine connections between race theory, black studies, and identity politics, McBride is the editor of James Baldwin Now (NYU Press, 1999), and co-editor of a special issue of Callaloo: A Journal of African-American and African Arts and Letters entitled "Plum Nelly: New Essays in Black Queer Studies" (2000). McBride's other works include Impossible Witnesses: Truth, Abolitionism, and Slave Testimony (NYU Press, 2002), Black Like Us: A Century of Lesbian, Gay and Bi-Sexual African American Fiction (Cleis Press, 2011), and Why I Hate Abercrombie and Fitch: Essays on Race and Sexuality (NYU Press, 2005). McBride has co-edited several collections and posthumous volumes, including A Melvin Dixon: Critical Reader (Mississippi University Press, 2006), Racial Blackness and the Discontinuity of Western Modernity (University of Illinois Press, 2013), and The Delectable Negro: Human Consumption and Homoeroticism within U.S. Slave Culture (NYU Press, 2014). He is currently at work on two new book manuscripts, tentatively titled, "Poetics, Politics, and Phillis Wheatley," and "White Lies in the Republic: Race, Sexuality, and the Law." 